\title{
APAKAH MEMILIH SAHAM DAFTAR EFEK SYARIAH INDONESIA DENGAN ANALISIS TEKNIKAL AKAN MENGUNTUNGKAN?
}

\author{
Basrowi, ${ }^{1}$ Fauzi, ${ }^{2}$ Pertiwi Utami ${ }^{3}$ \\ ${ }^{1}$ Sekolah Tinggi Ekonomi dan Bisnis Islam (STEBI) Lampung \\ Email: basrowi2018@gmail.com \\ ${ }^{2}$ Sekolah Tinggi Manajemen Informatika dan Komputer (STMIK) Pringsewu \\ Email: drfauzistmikpsw@gmail.com \\ ${ }^{3}$ Pascasarjana Universitas Islam Negeri (UIN)Raden Intan Lampung \\ Email: utamipertiwi89@gmail.com
}

\begin{abstract}
The purpose of this research is to find out whether stocks listing Indonesian Islamic securities using technical analysis will provide benefits. Because, most likely for beginners will have difficulty using technical analysis that looks like a chart. The research method uses literature study with Islamic economics approach. The results of the study found that there are specific strategies used to read price movements using technical analysis and if they do not understand and predict price movements well then the losses will be obtained. Technical analysis that is used to determine price movements by giving signals on the time of entry and exit of the stock market on listed companies listed on the Islamic securities list is not much different from that generally used on the capital market. It's just that the prohibitions and provisions of both the product, distribution, and operations that must be in accordance with the principles of sharia and this technique are advised not to be used to calculate long-term benefits, but in the short term can generate a positive return on investors.
\end{abstract}

Keywords: Stocks, Sharia Securities List, Technical Analysis

\begin{abstract}
Abstrak
Tujuan penelitian adalah untuk mengetahui apakah saham daftar efek syariah Indonesia dengan menggunakan analisis teknikal akan memberikan keuntungan. Karena, kemungkinan besar bagi pemula akan kesulitan menggunakan analisis teknikal yang nampak seperti chart. Metode penelitian menggunakan studi literatur dengan pendekatan ekonomi syariah. Hasil studi menemukan bahwa ada strategi khusus yang digunakan untuk membaca pergerakan harga menggunakan analisis teknikal dan apabila tidak memahami dan memprediksi pergerakan harga dengan baik maka kerugian yang akan diperoleh. Analisis teknikal yang digunakan untuk mengetahui pergerakan harga dengan memberi sinyal waktu masuk dan keluar pasar saham pada emiten yang terdaftar di daftar efek syariah tidak banyak berbeda dengan umumnya yang digunakan pada pasar modal. Hanya saja larangan dan ketentuan baik produk, distribusi, dan operaionalnya yang harus sesuai dengan prinsip syariah dan teknik ini disarankan tidak digunakan untuk memperhitungkan keuntungan jangka panjang namun dalan jangka pendek dapat menghasilkanpengembalian yang positif pada investor.
\end{abstract}

Kata Kunci:Saham, Daftar Efek Syariah, Analisis Teknikal 


\section{PENDAHULUAN}

Daftar Efek Syariah adalah salah satu alternatif emiten yang dapat dibeli sahamnya oleh para investor. Walaupun masih sangat dini untuk mengetahui apakah daftar efek syariah dapat secara konsekuen akan memberikan keuntungan jangka panjang bukan berarti lantas emiten ini tidak termasuk dalam perhitungan. Sejauh ini, prinsip-prinsip syariah pada beberapa perusahaan dan UMKM nyatanya mampu bertahan pada krisis perekonomian Indonesia. Sedangkan Analisis teknikal digunakan untuk menilai harga saham yang semakin sulit oleh para pemain trading dan investor terutama untuk membuat keputusan buy dan sell. Kemudian lantas kedua variabel ini dapat bekerjasama.

High return dalam bentuk capital gain dan deviden dapat diperoleh dengan melakukan bisnis investasi di pasar modal. Namun tentunya akan selalu ada resiko capitol loss yang harus diperhatikan. Bagi investor saham memahami saham dengan membaca pergerakan saham secara keseluruhan sehingga layak ditawarkan adalah sesuatu yang penting. Misalnya dengan melihat pergerakan harga saham pada Indeks Saham Gabungan (IHSG), Pefindo25, dan IDX30.(cermati.com, 2017)

Perubahan dinamis dari pasar saham dan beberapa pengaruh pada harga saham, menilai harga saham menjadi semakin sulit. Terutama pada saat berurusan dengan informasi tentang stok, individu akan cenderung untuk mmperkuat pentingnya untuk memperoleh informasi yang tersedia dan berkorelasi sendiri. Hal ini tentunya terkait dengan kebiasaaan yang bertentangan dengan pengambilan keputusan investasi yang objektif dan masuk akal.

Salah satu analisis yang dapat dilakukan adalah menggunakan analisis teknikal. Namun analisis semacam ini terlihat sederhana karena bentuknya seperti grafik yang mengarah keatas atau kebawah namun sesuatu yang cukup sulit apabila tidak memiliki pengetahuan yang cukup sepertihalnya seorang trader forex.

Saham daftar efek syariah juga adalah sesuatu yang baru, investor lebih mengenal pasar saham konvesional yang lebih dahulu masuk dalam ranah pasar modal.Saham syariah di Indonesia terdiri dari dua jenis yaitu saham yang disetujui oleh OJK Nomor 35/PJOK.04/2017 tentang kriteria dan Penerbitan Daftar Efek Syariah, dan yang kedua adalah saham yang terdaftar sebagai saham syariah oleh emiten masyarakat syariah berdasrkan pada peraturan OJK No. 17/PJOK.04/2015.(idx.co.id, 2019)

Menurut Kiyosaki (2002), "Banyak orang umumnya beranggapan bahwa investasi dilakukan oleh orang yang sukses dan berpenghasilan besar padahal persepsi seperti itu adalah salah besar. Karena yang benar adalah bahwa kita harus melakukan investasi oleh karena itu akan menjadi kaya, bukan malah sebaliknya.

Tujuan penelitian ini bermaksud untuk memberikan kontribusi ilmu pengetahuan tentang manfaat analisis teknikal pada saat membuat keputusan berinvestasi pada daftar efek syariah. Pada dasarnya, analisis teknikal telah lama digunakan sejak tahun 1978 yang diperkenalkan oleh Wilder. Namun seiring perkembangannya telah banyak digunakan pada semua jenis pasar termasuk dalam pasar saham. Analisis teknikal memang bukan sesuatu yang baru namun ketika digunakan dalam daftar efek syariah, lantas apakah akan sama hasil yang diperolehnya. Apakah akan memberikan keuntungan, dan langkah strategis apa yang daapt dilakukan. Analisis teknikal yang digunakan tidaklah terlihat sederhana seperti penampakannya. Tentu ada sejumlah kata asing atau bahkan chart berwarna yang nampak mencolok yang bagisebagaian 
pemula nampak asing dan sulit untuk dipahami. Oleh karena itu, melalui penelitian ini dengan berfokus pada saham yang terdaftar pada daftar efek syariah kemudian akan dijelaskan secara sederhana mengenai fungsi dan indikator analisis teknikal yang dapat digunakan beserta contoh chartnya.

\section{LANDASAN TEORI}

\section{Saham}

Saham merupakan bukti penyertaan atau kepemilikan individu dalam suatu perusahaan atau perseroan terbatas dengan beberapa jenis dari segi kemampuan dalam hak tagih atau klaim yaitu: 1) saham biasa (common stocks) yaitu bisa melakukan klaim terhadap kepemilikan pada semua penghasilan dan aktiva yang dimiliki perusahaan. Namun owner memiliki kewaijban yang terbatas dengan kerugian sebatas pada besarnya investasi pada emiten tersebut; 2) saham preferen (preferred stocks) yang didesain sebagai gabungan antara obligasi dan saham biasa. Karakteritiknya sama seperti pada saham umumnya yaitu menghasilkan pendapatan tetap seperti bunga obligasi, dapat melakukan klaim ats laba dan aktiva sebelumnya dan saham bisa mewakili kepemilkan ekuitas dan diterbitkan tanpa tanggal jatuh tempo.(cermati.com, 2015)

Berdasarkan segi cara peralihannya dibedakan menjadi dua jenis yaitu; 1) Saham Atas Unjuk (Bearer Stocks) yang tidak tertulis nama pemiliknya agar mudah dipindahtangankanpada owner lain dan yang mempunyai saham adalah sah secara hukum dan berhak mengikuti Rapat Umum Pemegang Saham (RUPS); 2) Saham Atas Nama (Registred Stocks) yang nama ownernya tertulis dan peralihan dilakukan melalaui serangkaian prosedur. Sedangkan jenis sahamdari segi kinerja perdagangannya terdiri dari lima jenis sebagai berikut; 1) Blue Chip Stocks yang mempunyai reputasi tinggi dan mempunyai pendapatan emiten yang stabil dan konsisten dalam membayar deviden; 2) Income Stocks memiliki keunggulan dalam kemampuan emiten untuk membayar deviden lebih tinggi dari rata-rata deviden yang dibayarkan pada taun sebelumnya; 3) Growth Stocks terdiri dari dua yaitu well-known dan lesser-known yang mempunyai pertumbuhan pendapatan cukup tinggi dengan reputasi tinggi; 4) Speculative Stoks berpotensi menghasilkan keuntungan yang tinggi di masa yang akan datang tetapi tidak mampu memberikan keuntungan konsisten dari tahun ke tahun; dan 5) Counter Cyclical Stocks mempunyai tingkat kestabilan yang tinggi pada saat krisis ekonomi karena tidak terpengaruh oleh kondisi ekonomi makro dan situasi bisnis yang ada.(cermati.com, 2015)

Jenis saham yang terakhir adalah yang terdaftar dalam Bursa Efek Indonesia (BEI) yaitu Exchange Trade Fund(ETF) yang merupakan gabungan dari reksadana terbuka dan saham serta pembelian di bursa dengan sistem berbasis layanan satu pintu. ETF terbagi menjadi dua jenis yaitu ETF index dimana investor bisa mengalokasikan dananya dalam bentuk portofolio efek yang terdapat di satu indeks tertentu dengan proporsi yang sama. Dan Close and ETFs yang khusus diperdagangkan di bursa efek dalam bentuk investasi tertutup dan dikelola secara aktif.(cermati.com, 2015)

Untuk menjadi saham yang memiliki efek syariah harus memenuhi syarat-syarat antara lain; 1) usaha yang dilakukan emiten harus berdasarkan prinsip-prinsip syariah baik dalam akad/perjanjian, aktivitas produksi, barang/jasa yang diproduksi maupun distribusi 
opersionalnya; dan 2) emiten harus mempunyai anggota direksi dan anggota komisaris yang memiliki pengetahuan tentang syariah.(kompasiana, com, 2016)

Kriteria yang lebih spesifik dalam pasar modal syariah di Indonesia adalah Pertama, emiten tidak melakukan kegiatan usaha antara lain; a) perjudian; b) perdagangan yang dilarang menurut syariah yaitu perdagangan yang tidak ditawarkan denan penyerahan barang/jasa dan penawaran dan permintaan palsu atau mengandung unsur penipuan; c) jasa keuangan ribawi dan jual beli resiko yang mengandung tantangan (gharar)/ judi (maysir); d) memproduksi, mendistribusikan dan memperdagangkan atau menyediakan barang/jasa haram zatnya (haram li-dzathi), barang/jasa haram bukan zatnya (haram li-ghairihi) yang telah ditentukan oleh Fatwa Dewan Syariah Nasional (DSN) Majelesi Ulama Indonesia (MUI), dan barang yang dapat merusak moral dan mengandung keburukan (modarat); dan e) melakukan transaksi yang mengandung unsur suap (riswah). Kedua, emiten harus memenuhi dua syarat rasio keuangan yaitu; a) total utang yang berbasis bunga dibandingkan dengan total aset tidak lebih dari $45 \%$ (empat puluh lima per seratus); dan b) total pendapatan bunga dan pendapatan tidak halal lainnya dibandingkan dengan total pendapatan usaha dan pendapatan lainnya tidak boleh lebih dari 10\% (jumlah per seratus).(idx.co.id, 2019)

\section{Analisis Teknikal}

Analisis teknikal merupakan pergerakan harga mata uang yang didasrkan pada pergerakan harga mata uang itu sendiri di masa lampau dengan tiga dasar persepsi yaitu,"1). Market Price Discount Everthing tercermin dari chat atau grafik yang mempengaruhi pasar; 2) Price Moves in Trend dimana harga tidak bergerak secara acak melainkan berlangsung dalam satu pola (trend) dan akan terus berlangsung sampai ada tanda-tanda bahwa pola pergerakan berhenti dan berbalik arah; dan 3) History Repeats Itselfadalah perilaku menyikapi informasi pasar di masa lalu sama dengansaaat ini (Murphy, 1999).

Ada beberapa bentuk teknikal statistik yang dapat digunakan diantaranya adalah grafik (chart);garis trend (trend line); support dan resistence;Overbought and Overrsold; danChart Pattern(Edwards, Magee, \& Bassetti, 2018). Pertama,Jenis grafik (chart) dalam analisis teknikal adalah yang paling utamam dan merupakan satu-satunya objek analisa. Dibawah ini contoh jenis chart yang digunakan antara lain;

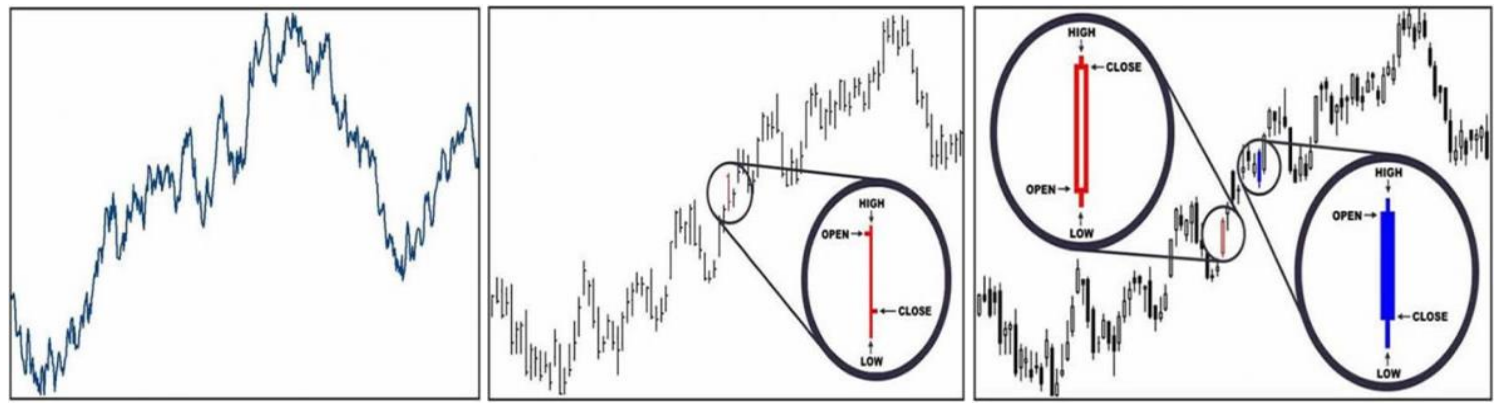

Gambar 1.Line Chart; Bar Chart; Candlestik Chart

Sumber: seputarforex.com, 2019

Kedua, Garis trend (Trend Line) yaitu kecenderungan pergerakan dalam satu arah harga dengan asumsi bahwa harga akan bergerak dalam sebuah kecenderungan itu sendiri. Garis trens 
terbagi menjadi tiga yaitu; Tren meningkat atau uptrend (Bullish Market), Trend menurun atau down trend (Bearish Market), dan Trend mendatar atau horizontal trend (Sideways/Consolidation) sebagaimana dapat dilihat pada gambar berikut ini;

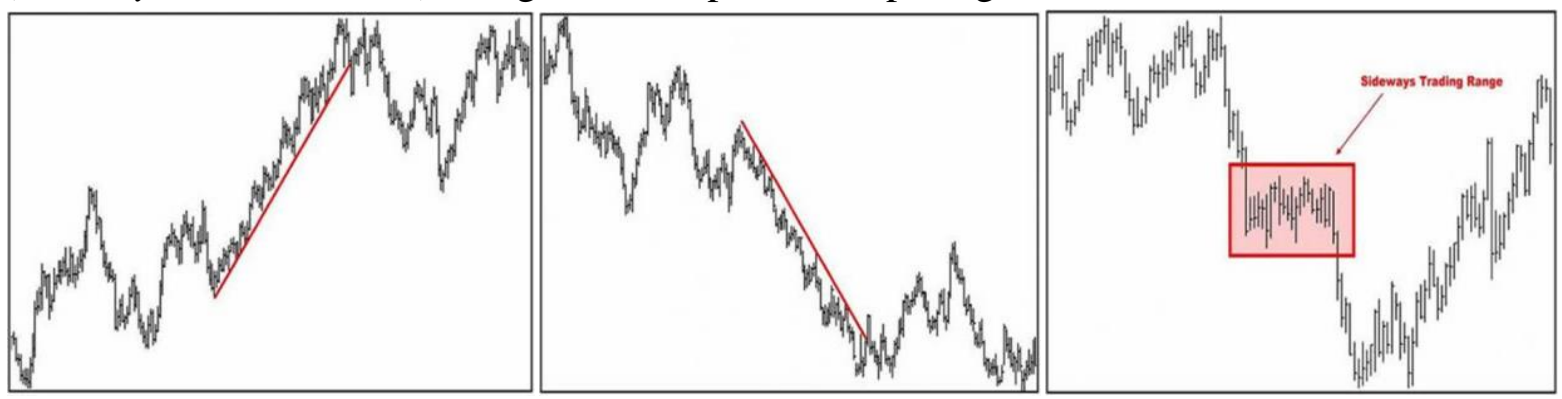

Gambar 2. Garis tren uptrend (Bullish Market); downtrend (Bearish Market);

Horizontal trend (Sideways/Consolidation)

Sumber: seputarforex.com, 2019

Ketiga, Support and Resistance berfungsi untuk mengindikasi batas atas maupun batas bawah dari pergerakan harga sebagaimana pada gambar berikut ini;

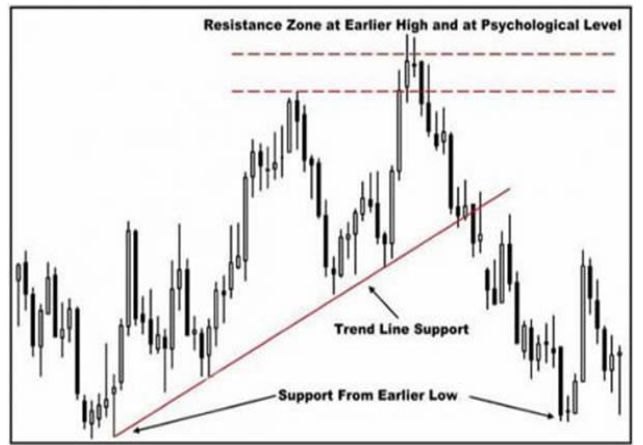

Gambar 3. Trend Line Support and Resistance

Sumber: seputarforex.com, 2019

Support sebagai batas bawah/range pada titik /range harga akan timbul minat untuk membeli yang lebih kuat dari minat jual sehingga mengakibatkan terjadinya kelebihan permintaan yang akan meningkatkan harga di pasar dan menghentikan trend penurunan harga. Sedangkan Resistance adalah sebaliknya minat jual lebih tinggi daripada minat beli yang mengakibatkan turunnya harga di pasar dan menghentikan kenaikan harga.

Keempat, Overbought and Oversold yaitu kondisi dimana pasar memiliki tingkat kejenuhan tertentu. Overbought adalah situasi yang tingkat kejenuhan akan banyaknya permintaan yang menyebabkan harga cenderung bergerak turun atau melemah.Sedangkan Oversold adalah dimana pasar menjadi jenuh karena banyaknya penawaran sehingga harga menjadi cenderung naik atau menguat. Dan yang terakhir adalah Chart pattern berupa pola pergerakan yang digunakan sebagai tanda perubahan suatu trend tertentu yang terdiri dari tiga jenis pola sebagai berikut; a), Reversal Pattern yang mempunyai beberapa pola diantaranya: 

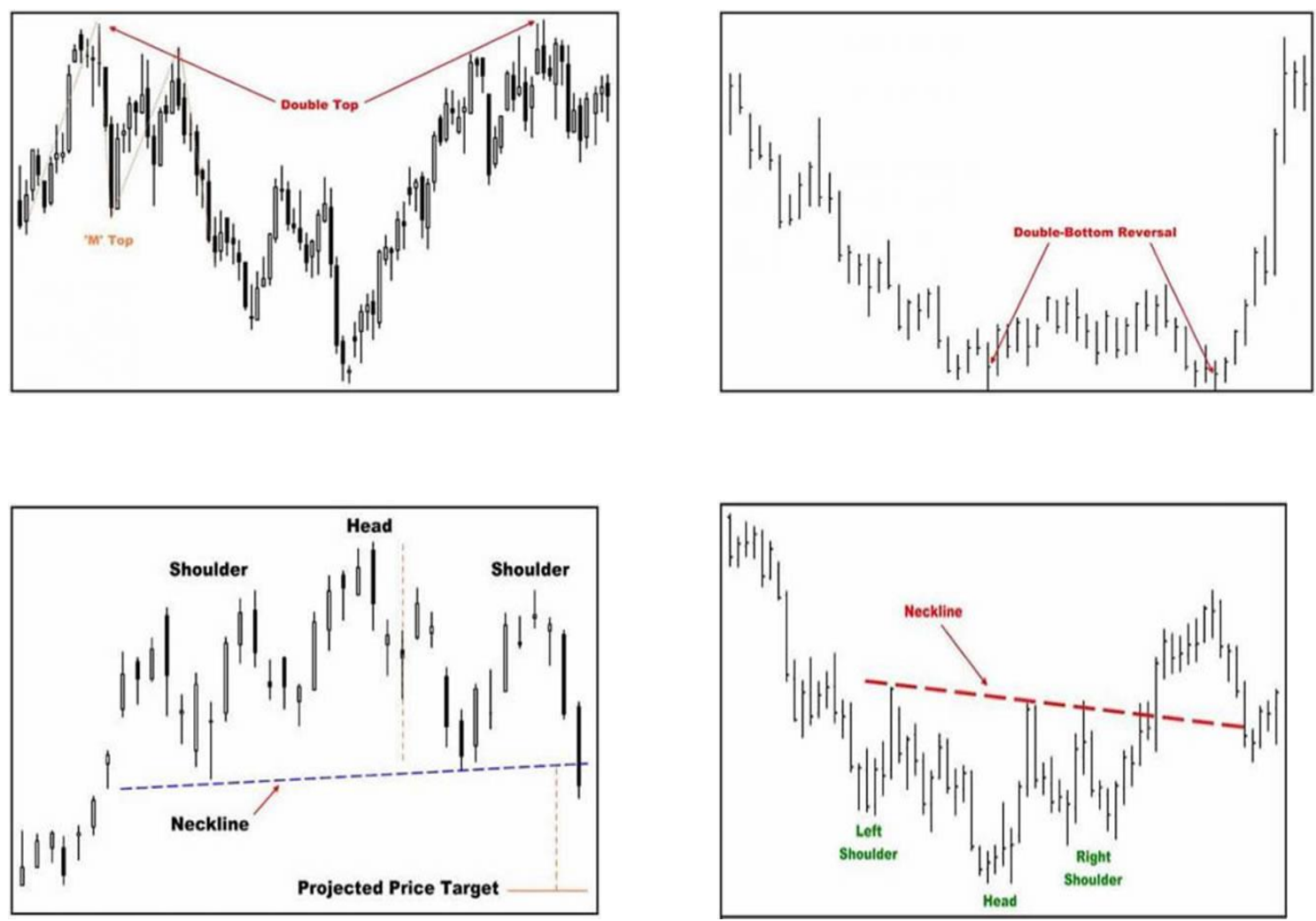

Gambar 4. Double Tops; Double Bottoms; Head and Shoulders top reversal;

Head and botton reversal;

Sumber: seputarforex.com, 2019

b) Continuation Pattern dimana terdapat perubahan ke trend awal yang dominan. Contohnya adalah harga bergerak dalam uptrend kemudian berubah menjadi downtrend (retrace) dan meneruskan lagi ke uptrend sebelumnya atau sebaliknya. Adapun beberapa pola pergerakan diantaranya adalah;
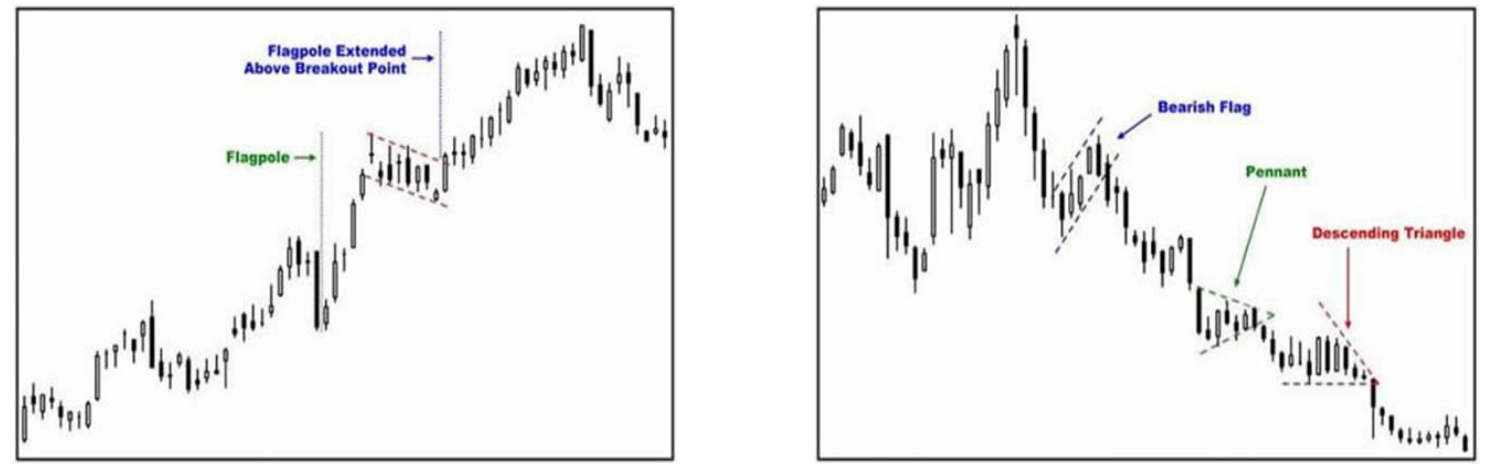



Gambar 5. Bullish Flags; Bearish Flags; Ascending Triangle; Cup and Saucer

Sumber: seputarforex.com, 2019

3) Gap merupakan bentuk pola chart yang memiliki jarak atau celah antara 2 chart yang saling berdekatan yaitu apabila nilai low dari chart sebelumnya lebih tinggi dari pada nilai chart berikutnya dan sebaliknya. Adapun tiga bentuk utama dari gap antara lain;

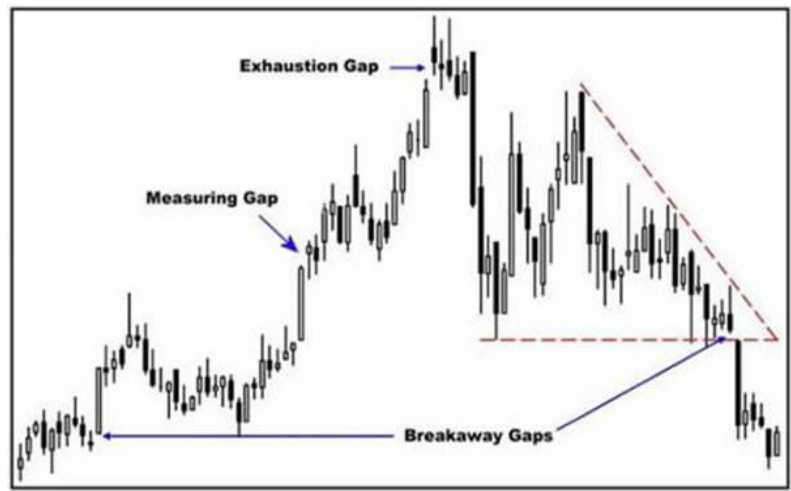

Gambar 6. Break away gap; Measuring gap; Exhausting gap

Sumber: seputarforex.com, 2019

Secara umum, terdapat tiga jenis indikator dalam analisa chart yaitu; 1) Price Momentum Indicator (Oscillator) untuk mengidentifikasi situasi oversold atau overbought. (Edwards, Magee, \& Bassetti, 2018). Contoh indikator; a) Stochastic Oscillator yaitu menunjukkan saat dimana pergerakan harga telah mencapai keadaan overbought atau oversold. Indikator ini diciptakan oleh George C. Lane pada tahun 1950-an. Versi yang digunakan adalah slow stochastic yang terdiri dari dua garis kurva yang menyerupai moving average.

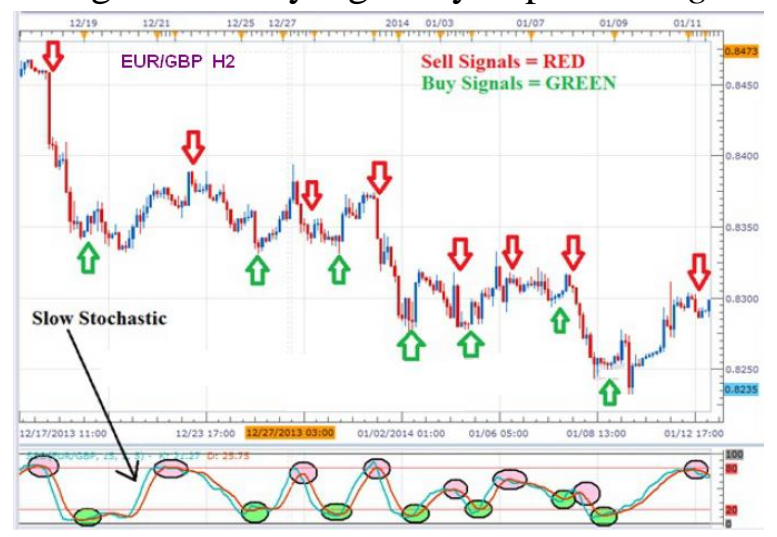

Gambar 7.Stochastic pada chart pergerakan harga saham 
Pergerakan kurva dibatasi oleh level 0 hingga 100 yang menunjukkan persentasi nilai indikator. Ke 2 garis kurva adalah \%K yang biasanya ditampilakn dengan warna biru, dnagaris $\% \mathrm{D}$ dengan warna merah. $\% \mathrm{D}$ adalah nilai rata-rata dari $\% \mathrm{~K}$ sehingga pergerakannya lebih lambat (lagging). Pergerakan kedua garis ini mengidentifikasi perilaku trend yang sedang terjadi. Indikator oscillator akan memberikan sinyal ketika momentum pergerakan harga sedang melemah yang merupakan syarat akanterjadinya koreksi ataupun pergantian trend.

b) Relative Strength Index (RSI) merupakan indikator oscillator yang dibuat oleh Welles Wilder pada tahun 1978 dan digunakan dalam trading di semua jenis pasar. Indikator RSI digunakan untuk menentukan waktu entry yang tepat dengan melihat level overbought dan oversold serta melakukan deteksi kemungkinan pergantian arah trend dengan mengamati divergensi terhadap pergerakan harga. Indikator ini dibuat untuk membandingkan jumlah perubahan yang positif (lebih tinggi) dengan perubahan harga yang negatif (lebih rendah) untuk jangka waktu tertentu. Rasio diplot dalam range 0 sampai dengan +100 . Apabila pada jangka waktu tertentu pergerakan harga tidak berubah maka RSI akan tetap pada kondisi overbought atau oversold.(Wilder, 1978)

c) Indikator Commodity Channel Index (CCI) dikenalkan oleh Donald Lambert pada tahun 1980 sebagai sebuah alat bantu untuk trading komoditi namun kemudian digunakan untuk semua jenis pasar. Menurut Lambert (1980) CCI merupakan bawaan pada Metatrader yang terdiri dari tiga komponen yaitu garis sinyal CCI, area overbought, dan area oversod dan digunakan untuk mengukur perbedaan antara harga tengah, pergerakan harga, dan rata-rata dari harga tengah dalam jangka waktu tertentu. Cara membaca CCI dapat dilakukan dengan melihat sinyal CCI pada saat sinyal CCI berada di atas 100, maka harga sedang Uptrend. Dan sebaliknya, apabila garis sinyal CCI berada di bawah nilai -100, maka harga sedang Downtrend. Untuk lebih jelasnya dapat dilihat pada gambar berikut ini;

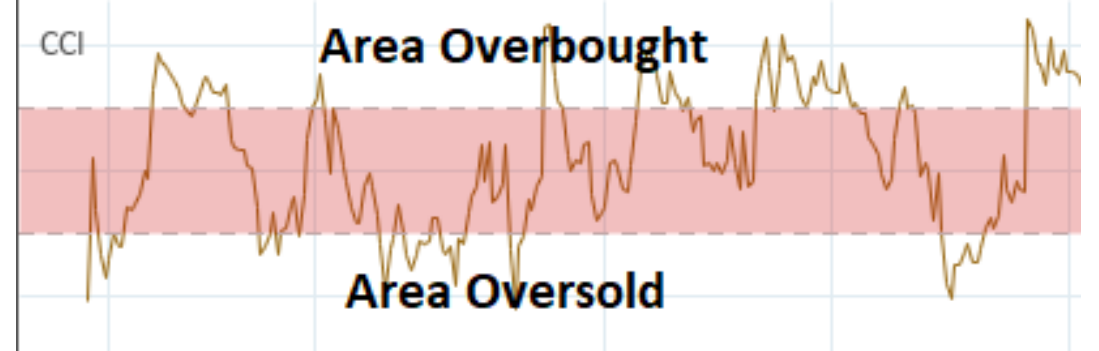

Gambar 8. Contoh Pergerakan indikator Commodity Channel Index (CCI) Sumber: seputarforex.com, 2013

Dari gambar diatas dapat diterangkan bahwa ketika garis sinyal CCI mengarah ke atas, berarti pasar sedang dalam keadaan bullish. Sebaliknya ketika garis sinyal CCI mengarah ke bawah, maka pasar dalam keadaan bearish. 
Adapun beberapa cara meggunakan indikator CCI diantaranya; a) untuk melihat tingkat kejenuhan pasar (Overbought dan Oversold) sebagaimana gambar di bawah ini;



Gambar 9. Contoh Commodity Channel Index (CCI) untuk melihat Overbought and Oversold

Sumber: seputarforex.com, 2013

Dalam kondisi Overbought, garis sinyal CCI akan berada di atas +100 , dan dalam kondisi Oversold, garis sinyal CCI akan berada pada level -100.

2) Trend Following Indicator yang digunakan untuk mengidentifikasi awal dan akhir suatu tren atau kapan suatu trend akan berubah sehingga dapat membuat keputusan yangtepat untuk membuka atau menutup posisi. Contoh indikator yang digunakan adalah Moving Average yaitu indikator yang menghaluskan pergerakan harga dengan menyaring fluktuasi harga yang sifatnya acak, mengikuti trend-following dan lagging karena dibuat berdasarkan harga yang telah terjadi sebelumnya. MA dihitung berdasrkan nilai rata-rata pergerakan harga pada jangka waktu tertentu. Nilai rerata dapat diambil dari harga tertinggi, terendah, harga pembukaan, penutupan ataupun harga terendah. Dimana semakin panjang jangka waktu yang digunakan dalam perhitungan indikator MA, maka pergeraka garis akan semakin melambat dibandingkan harga.

3) Directional Movements index (DMI) Volatility Indicator, DMI memiliki indikator yang disebut dengan Parabolic SAR yaitu indikator teknikal yang dibuat oleh Wilder pada tahun 1978. Parabolic Sar mempunyai tiga macam fungsi yaiti dapat menentukan arah tren, sebagai patokan entry, dan posisi exit dan trailing stops. Dalam tampilan pada Metatrader 4, Indiaktor Parabolic SAR akan muncul sebagai sebuah titik-titik pada bagiat atas atau bawah candlestik.

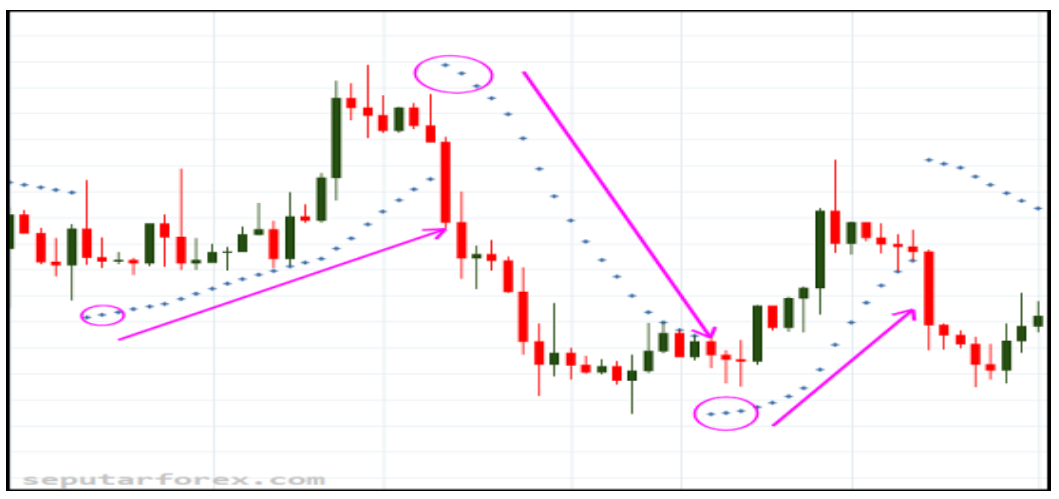




\section{Gambar 10. Contoh Indiaktor Parabolic SAR}

Sumber: seputarforex.com, 2018

Titik-titik yang muncul di bagian bawah candlestick menandakan tren market sedang dalam keadaan Buliish. Sedankgna apabila titik-titik SAR muncul di bagian atas candlestick hal ini berati bahwa tren pasar sedang dalam keadaan (Bearish)

4) Indikator Volatilitas memiliki kegunaan untuk melihat kekuatan pasar dengan memperhatikan fluktuasi harga dalam jangka waktu tertentu. Pasar dapat dikatakan mempunyai volatility yang cukup tinggi apabila terjadi pergerakan harga yang berlangsung naik turun secara tajam atau sangat fluktuatif dimana terjadi selisih harga yang besar antara harga tertinggi dan terendah.(Bollinger, 2002)

Indikator yang digunakan adalah Indikator Bollinger Bonds untuk mengukur volatititas serta trading pada saat pasar sideways. Ciri khasnya dalam kkondisi pasar sideways (ranging), harga bergerak diantara dua band (pita). Indikator ini diperkenalkan oleh John Bollinger pada tahun 1980 dan sering digunakan pada jenis pasar finansial. Bollinger Bands daapt ditemjukan pad platform trading termasuk dalam Metatrader dengan parameter default SMA: 20 priode, dan standar deviasi:2

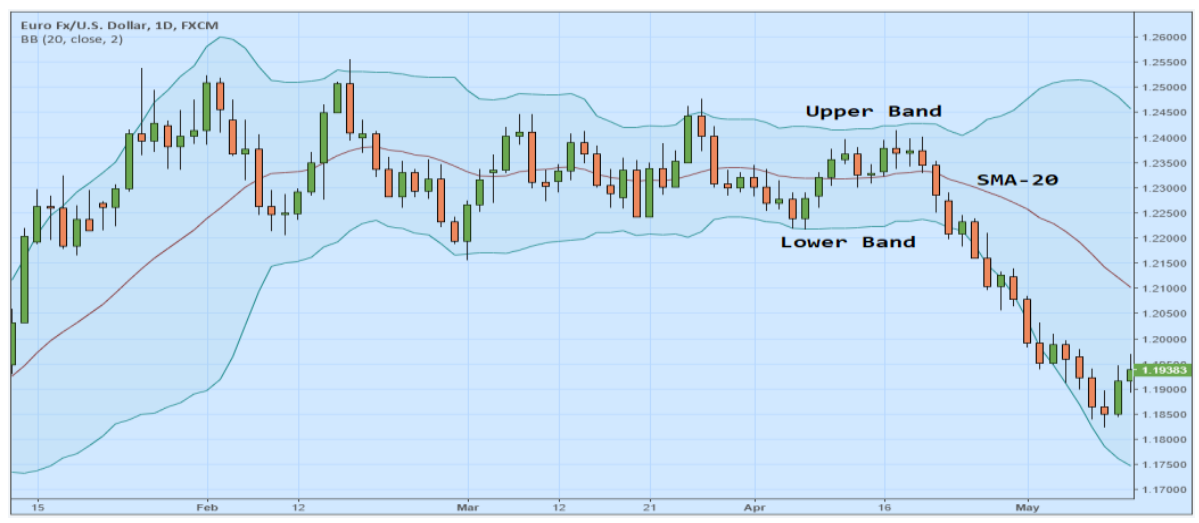

Gambar 11. Bollinger Bands pada platform trading

Sumber: seputarforex.com, 2013

Pada umumnya, kondisi dinyatakan overbought terjadi apabila harga telah menyentuh Upper Band, tetapi harga penutupan (close) masih dibawah Upper Band. Sedangkan pada kondisi oversold apabila harga sudah menyentuh Lower Band, tetapi masih ditutup di atas Lower Band.

\section{METODE PENELITIAN}

Metode penelitian yang digunakan adalah studi kepustakaan dengan mengumpulkan sejumlah kajian yang bersumber yang relevan dari artikel, buku-buku, Internet, dan beberapa kajian lainnya yang memiliki hubungan dengan penelitian ini (Mardalis, 1999). Tentunya dalam melakukan penelitian ini akan membutuhkan tinjauan penelitian.

Penelitian ini untuk mengetahui sejauh mana analisis teknikal digunakan dan langkah strategis yang dapat dilakukan ketika memutuskan untuk membeli saham daftar efek syariah. 
Tinjauan pustaka berdasarkan prinsip-prinsip syariah juga digunakan untuk memperkokoh hasil penelitian yang diharapkan.

\section{DISKUSI DAN PEMBAHASAN}

Berdasarkan sejumlah penelitian terdahulu menemukan bahwa indikator pada analisis teknikal dapat digunakan untuk menghasilkan pngembalian yang positif yang signifikan. Di temukan bahwa perusahaan seperti Singapore Stock Exvchange (SES) akan cenderung memperoleh keuntungan besar dengan menerapkan indikator teknis. Ini daapt menajdi alasan mengapa sebagian besar investor memiliki tim perdagangan yang sangat bergantung pada analisis teknis.(Wong, Manzur, \& Chew, 2003)

Bahkan analisi teknik dapat dugunakan untuk mengetaaui efisiensi suatu pasar saham dan aturan perdangannya misalnya dengan menggunakan indeks DJIA dengan data intraday.Cervello-Royo, Guijarro, \& Minchniuk, 2015)

Sejumlah aplikasi pendukung untuk Sistem Analisis Teknis Saham telah banyak ditemukan. Sehingga para pemula tidak lagi akan kesulitan dalam menggunakan analisis teknikal ini. Misalnya saja aplikasi metratader 4 dan Esper. Berdasarkan Real-time Processing (STAS), beberapa model keuangan seperti model penetapan harga aset modal. Grafik Candlestick, Indeks KDJ, dan Indeks MACD diperkenalkan.(Ding, et al, 2017)

\section{Membaca Analisis Teknikal pada Perdagangan Saham}

Ada teknik tertentu yang dilakukan oleh seorang investor sebagai langkah strategis ketika memutuskan menggunakan analisis teknikal untuk membuat keputusan investasi pada emiten pada daftar efek syariah sebagaimana berikut ini; 1) mempelajari trend yang sedang terjadi baik jangka panjang, pendek, dan menengah dari Chart. Umumnya uptrend digunakan untuk menjual atau dengan menggunakan peluang 'buy', sedangkan untuk drowntrend digunakan dalam membeli atau mencari peluang 'sell'; 2) menentukan beberapa level suport dan resistance sebagai peringatan bagi trader. Trader dapat mencari posisi 'buy' atau sebaliknya 'sell' di area support saat trend pada posisi naik, maka bisa dilakukan tindakan cut loss; 3) Memanfaatkan Moving Average (MA) yang membantu untuk mengidentifikasi trend dimana harga bergerak dibawah MA.MA juga dapat berfungsi sebagai supoort dan resistance; 4) memfilter dengan indikator osilator dapat memberikan gambaran tentang kondisi pasar pada keadaan overbought (kondisi harga sudah tinggi) dan oversold (kondisi harga rendah); dan 5) melakukan level stop loss dan target profit dari sebuah transaksi saham emiten dengan tidak melupakan aturan risk, reward, dan ratio.

\section{Price Momentum Indicator (Oscillator)}

Untuk mengukur momentum menggunakan indikator oscillator pada Stochastic dalam analisis teknikal dapat dilakukan dengan dua cara yaitu; Pertama dengan melihat perpotongan garis kurva pada level-level ekstrem. Dan Kedua dengan menyesuaikan entry dengan trend pada time frame yang lebih tinggi untuk menghindari false signal sebagaimana pada gambar berikut ini; 




Figure 12. Analisis Teknikal dengan melihat Stochastic

Sumber: seputarforex.com, 2014

Investor tidak harus merespon setiap sinyal yang muncul, tetapi dapat mengambil sinyal yang probabilitasnya paling kuat. Seperti pada indikator stochactic oscilltator yang dibatasi oleh level o sampai dengan 100. Pada contoh gambar 9 dapat dilihat bahwa EUR/JPY diatas sinyal yang paling kuat terjadi pada titik-titik perpotongn (crossing) garis kurva $\% \mathrm{~K}$ dan $\% \mathrm{D}$ pada area overbought dan oversold. Investor dapat membeli sell pada saat overbought dan buy saat oversold. Kemudian, pada saat sedang trending dengan kuat (misalnya uptrend), maka pada time frame yang lebih rendah maka indikator stochastic oscillator aka nmenunjukkan keadaan overbought dan itu merupakan tanda sinyal yang salah (false signal). Apabila di entry sell, kemungkinan bisa fatal karena uptrend sedang kuat. Akan lebih baik menunggu stochastic oscillator pada time frame yang lebih rendah yaitu pada saat keadaan oversold sebagai sinyal buy. Intinya adalah indikator stochastic oscillator dapat menunjukkan momentum yang tepat untuk melakukan entry.(seputarforex.com, 2014)

Sedangkan apabila menggunakan indikator Relative Strength Index (RSI) maka dapat melakukan beberapa strategi diantaranya 1) pada saat keadaan trend yang kuat, abaikan overbought dan oversold indikator RSI. Karena pada jangka waktu yang relatif panjang, metode entry dengan mengandalkan keduanya pada indikaotr RSI menjadi tidak akurat lagi. Contoh kasus pada gambar berikut ini;

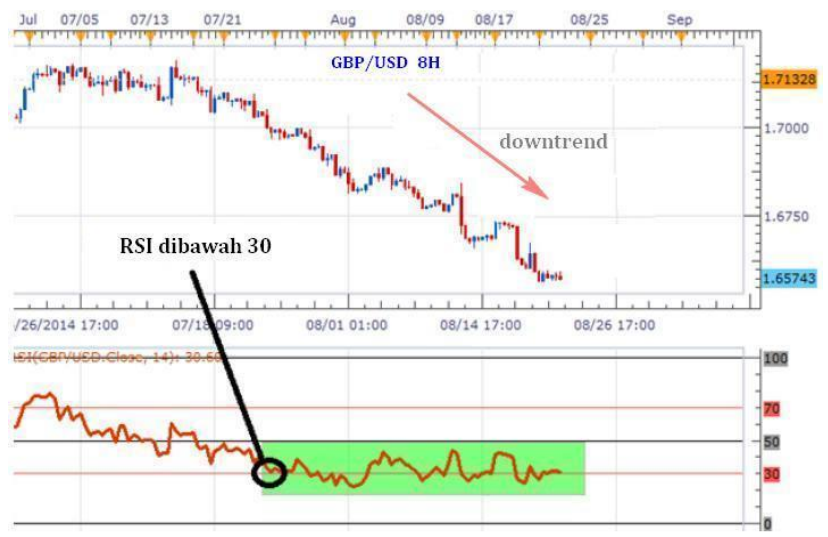

Gambar 13. Analisis Teknikal dengan melihat Relative Strength Index (RSI) Sumber: seputarforex.com, 2014 
Pada contoh GBP/USD di atas, dapat dilihat bahwa pergerakan downtrend sedang kuat dan RSI tetap berada pada area oversold untuk jangka waktu yang cukup lama. Apabila melakukan buy ketika oversold, maka akan menyebabkan kerugian. Langkah yang dapat diambil adalah sebelum mengamati indikaotr RSI, trader/investor harus melihat indikator trend terlebih dahulu. Umumnya yang digunakan pada indikator trend adalah MACD, Bollinger Bands, dan ADX.

Trader/investor harus memperhatikan level 50 pada indikaotr RSI (center line). Pada saat center line ke arah atas, maka itu mengisyaratkan sinyal buy. Dan sebaliknya apabila menembus center line ke arah bawah, maka mengisyaratkan sinyal sell.



Gambar 14. Contoh Relative Strength Index (RSI) dengan memperhatikan level 50 Sumber: seputarforex.com, 2014

Pada contoh grafik GBP/USD di atas, dapat dilihat bahwa center line memiliki fungsi sebagai level support dimana pada saat indikator RSI break untuk kedua kalinya, harga akan beralih ke pergerakan downtrend.

Dan strategi terakhir adalah dengan mengunakan parameter indikator RSI yang disesuaikan dengan time frame trading. Menurut Wilder (1978) semakin kecil jangka waktu pengukuran, maka akan semakin sensitif sehingga menyulitkan pengmaatan; sedangkan jika jangka waktu semakin besar, maka akan semakin kurang sensitif sehigga dapat mempengaruhi akurasi pengukuran. Pada dasarnya, apabila semakin kecil setting periode, maka sinyal trading akan semakin sering dihasilkan. Contohnya pada Trader Harian diman time frame 1 jam ke bawah biasanya menggunkan RSI periode 9, sedangkan Scalper menggunakan periode 7. Sementara untuk trader jangka menengah dan panjang dapat menggunakan periode 14 atau 25 .

Apabila menggunakan indikator Commodity Channel Index (CCI) maka ada langkah yang harus dilakukan yaitu menghitung nilai indikator CCI. Kendala yang sering dihadapi investor adalah kesulitan dalam menghitung nilai indikator CCI secara manual. Oleh karena itu investor dapat menggunakan Metatrader 4 melalui menu Insert > Indicator > Oscillator > Community Channel Index. 


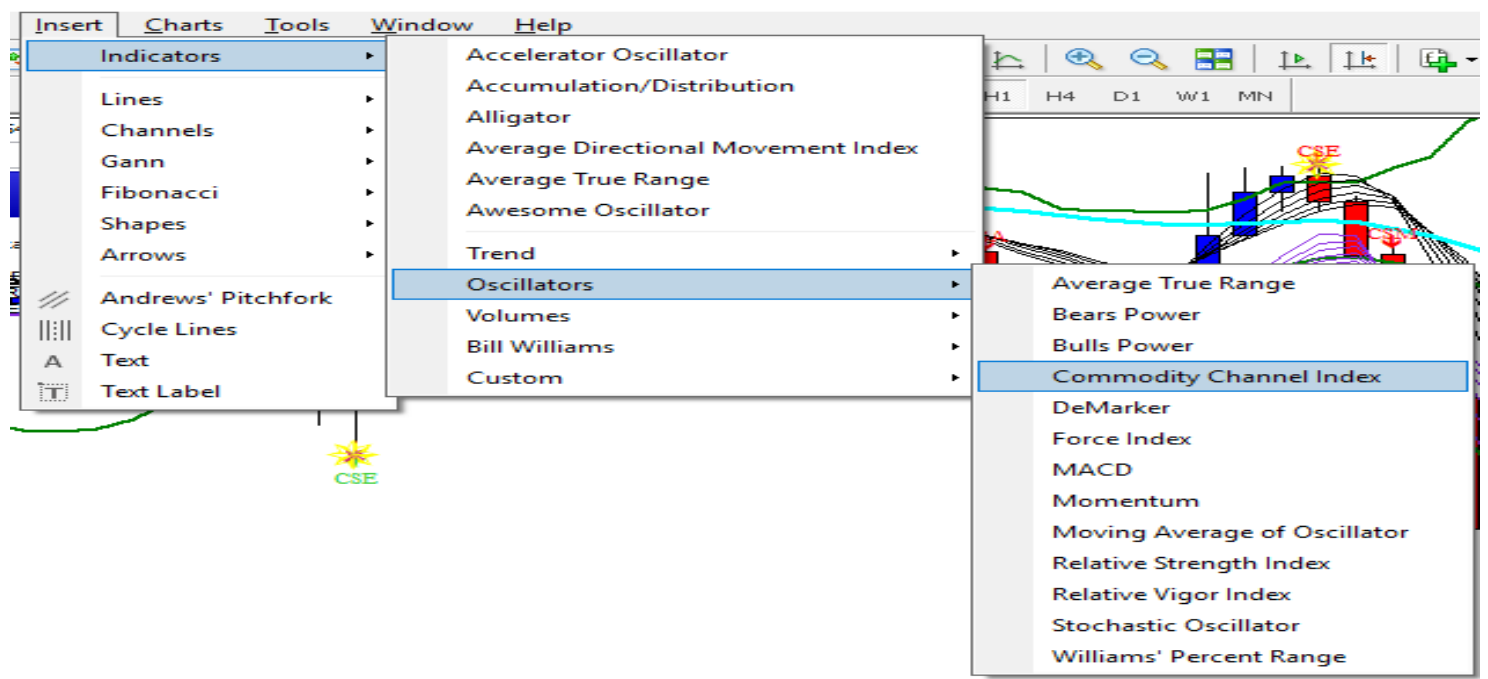

Gambar 15. Metatrader 4 untuk menghitung nilai CCI

Sumber: seputarforex.com, 2013

Menggunakan CCI dalam mengukur tingkat kejenuhan Overbold and Oversold harus dengan bantuan indikator lain. Karena jika tidak, akan banyak sinyal false yang berakibat fatal yaitu menderita kerugian. Hal ini dikarenakan CCI adalah indikator yang memiliki sifat lagging, sehingga sinyal yang akan dibentuk dapat berbeda antara saat ini dan saat penutupan candle.

Terkadang dalam sebuah perjalanan pasar, harga akan bergerak ke satu sisi dengan kuat dan terus menerus. Keadaan seperti ini dapat digunakan untuk meraih keuntungan. Dengan menggunakan indikator CCI, retracement dapat dideteksi sebagaimana pada contoh dibawah ini;



Gambar 16. Contoh Commodity Channel Index (CCI) untuk mendeteksi retracement

Sumber: seputarforex.com, 2013

Pada contoh diatas berupa pergerakan besar ke atas (Uptrend) yang terjadi di time frame H4 di EUR/USD. Kondisi retracement harga dimana turunlah pada satu tingkat time frame yang lebih kecil. Misalnya terjadi Overbought di chart H4, maka tunggu hingga terjadi kondisi 
Oversold pada time frame H1-nya. Setelah mencapai Oversold, investor daapt menggunakan konfirmasi candlestick sebagai penambah strategi.

Selain dua cara di atas, indikator CCI dapat digunakan untuk melihat Divergensi Market. Divergensi market adaalh sebuah kondisi dimana terjadi pergerakan harga dan indikaotr yang berbeda satu sama lainnya dan dapat menjadi salah satu sinyal yang menyebabkan munculnya reversal pada market.

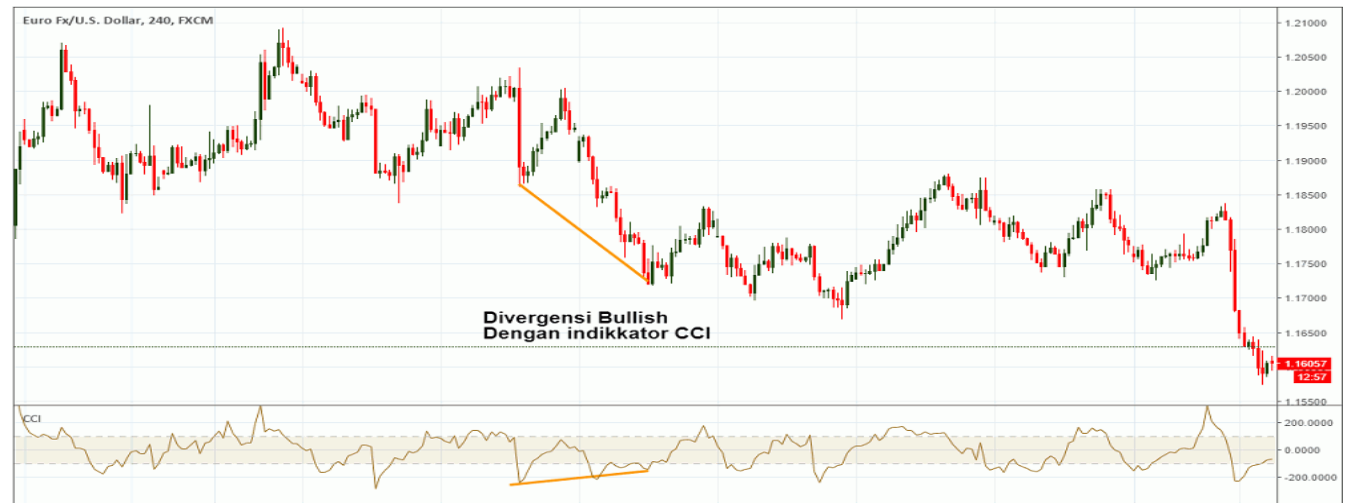

Gambar 17. Contoh Commodity Channel Index (CCI) untuk melihat Divergensi Bullish Sumber: seputarforex.com, 2013

Apabila terjadi pergerakan harga yang menunjukkan level Lower Low (LL), tetapi sinyal CCI menunjukkan Higher Low (HL) seperti pada gambar dapat diartikan bahwa adanya sinyal divergensi bullish; meski harga menurun, momentun pelemahnya melambat, harga dapat berbalik menjadi menguat kembali. Sedangkan untuk divergensi bearish, pergerakan harga justru akan membentuk level Higher High $(\mathrm{HH})$, tetapi sinyal yang dihasilkan menunjukkan Lower Low (LL) sebagaiman pada gambar dibawah ini;

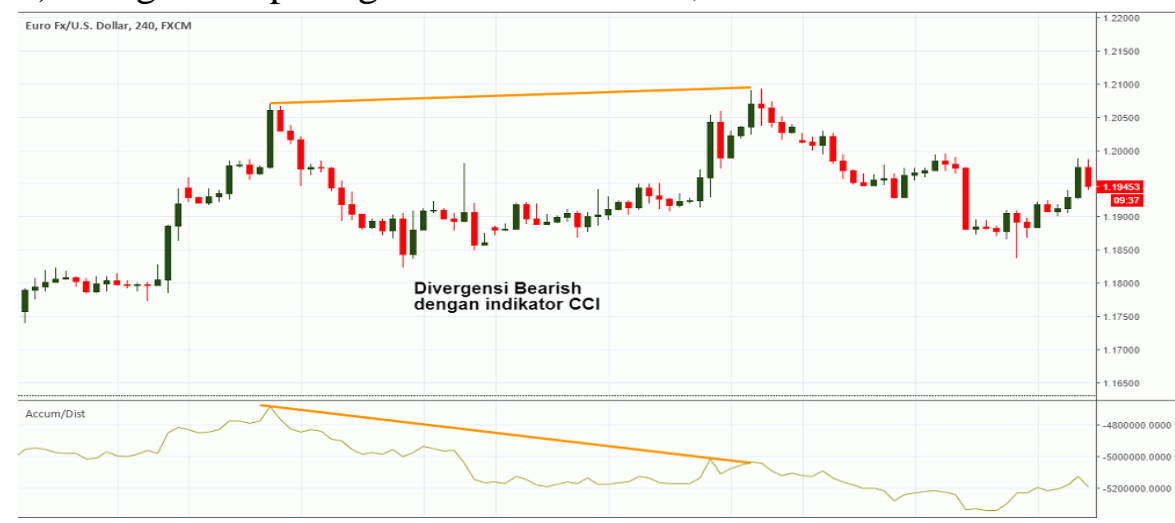

Gambar18. Contoh Commodity Channel Index (CCI) untuk melihat Divergensi Bearish Sumber: seputarforex.com, 2013

\section{Trend Following Indicator}

Salah satu analisis teknikal yang paling sederhana dan mudah digunakan adalah Indikator Moving Average. Apalagi seiring kemajuan teknologi tidak lagi sulit untuk menghitung trading harian karena Moving Average dapat dipasang otomatis pada sofware trading. Langkah-langkah yang digunakan pada platform Metatrader adalah dengan mengklik Insert > Indicators > Trend > Moving Average. 


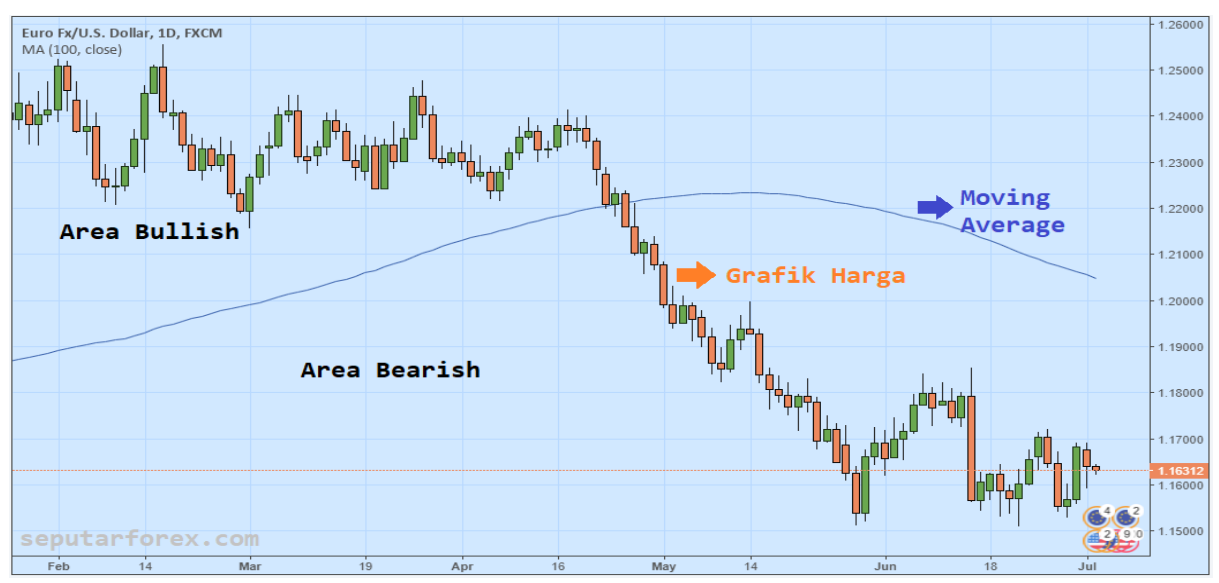

Gambar 19. Contoh Platform Metatrader pada Indikator Moving Average Sumber: seputarforex.com, 2018

Moving Average akanmuncul sebagai garis yang bertumpuk dengan grafik harga sebagaiman pada gambar diatas. Moving Average digunakan untuk tiga fungsi yaitu; 1) Identifikasi Tren Harga dengan melihat kondisi grafik harga dan garis Moving Average dimana apabila harga sekarang berada di bawah garis Moving Average, berarti trendBearish (harga cenderung akan menurun) dan apabila harga sekarang berada di atas garis Moving Average, berarti tren Bullish (harga akan cenderung naik); 2) sebagai Support-Resistance Dinamis dimana harga akan cenderung memantul jika suatu tren masih kuat, atau harga mengalami perubahan tren apabila tren sebelumnya melemah. Support-Resistance akan nampak bila investor menyusuri titik-titik pertemuan antara harga dan garis MA sebagaimaan contoh pada gambar di bawah ini;

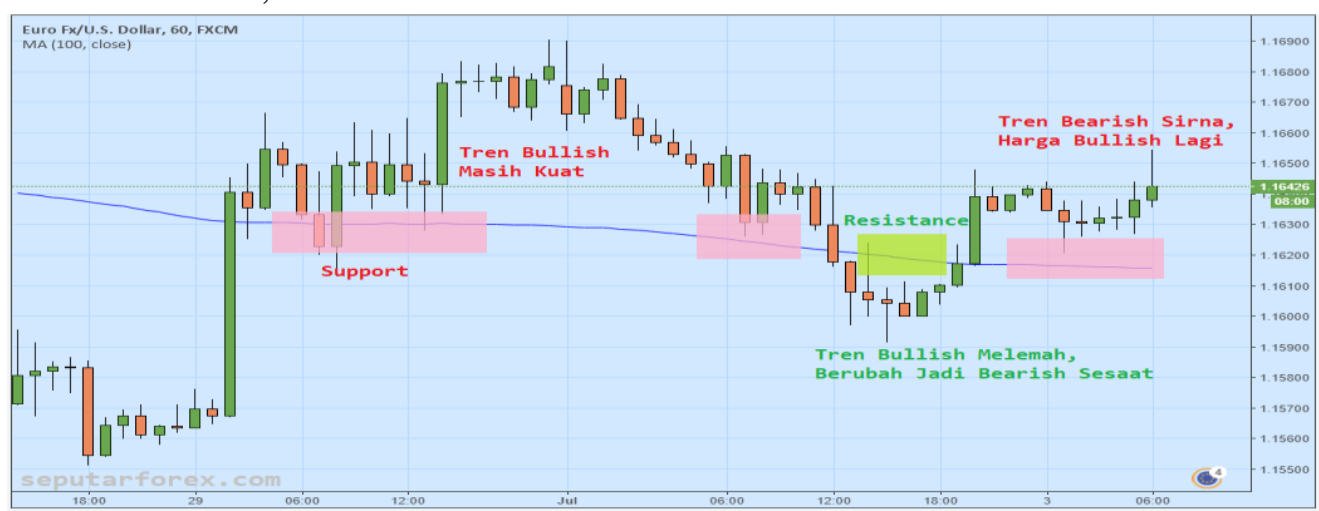

Gambar 20. Contoh Moving Average sebagai Support-Resistance Dinamis

Sumber: seputarforex.com, 2018

Pada saat harga bergerak naik di atas MA, maka garis MA memiliki peran sebagai Support. Sedangkan apabila harga bergerak di bawah garis MA, maka garis MA berperan sebagaiResistance. Candle harga yang memantul balik (bounce) dari garis MA memiliki arti bahwa tren sebelumnya masih kuat. Sedangkan candle harga yang bergerak menembus (break out) garis MA, dapat diartikan bahwa telah terjadi perubahan trend.

3) Menemukan Peluang Buy-Sell dengan menaruh dua garis MA pada jangka waktu tertentu di atas chart, kemudian melakukan pengamatan perlintasannya (crossover). Sinyal 
yang dihasilakn oleh MA disebut Golden Cross dan Death Cross. Misalnya MA dengan jangka waktu 5 dan jangka waktu 20 (MA-5 dan MA-20)

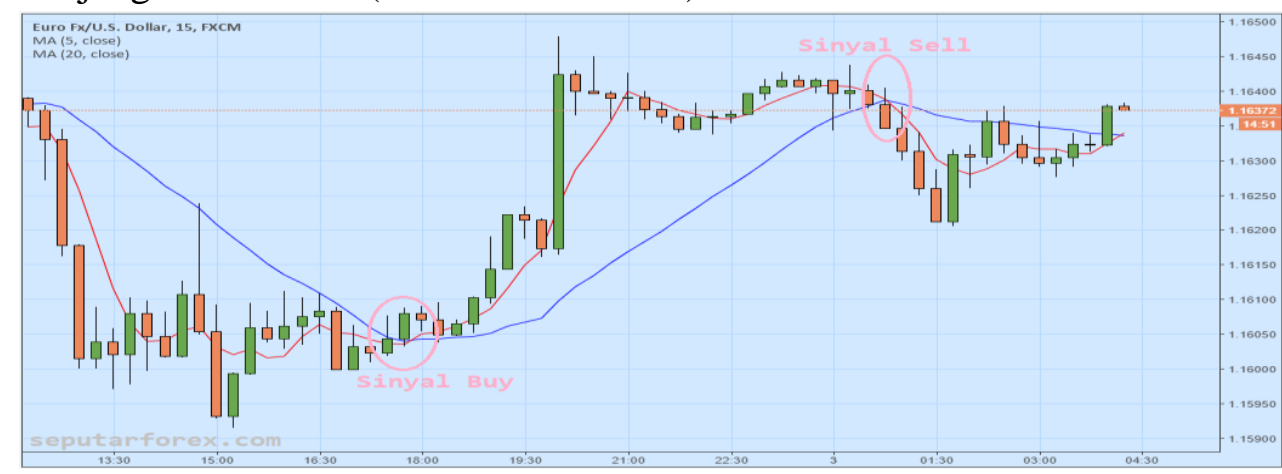

Gambar 21. Contoh Moving Average dengan cara menemukan pelaung Buy-Sell

Sumber: seputarforex.com, 2018

Aturan mengidentifikasinya adalah; “a) sinyal buy apabila garis MA berjangka waktu lebih rendah bergerak melintasi garis MA yang berperiode lebih tinggi. Pada contoh gambar ditas, perhatikan garis merah (MA-5) yang bergerak melintasi garis biru tua (MA-20) di bawah ke atas. Sedankgan b) Sinyal Sell apabila garis MA berjangka waktu lebih rendah melintasi garis MA berjangka waktu lebih tinggi dari atas ke bawah. Pad acontoh gambar diatas, perhatiakn dengan seksaman bagaimana garis MA-5 turun melintasi garis MA-20.

\section{Directional Movements Index (DMI) Volatility Indicator}

Indikator Parabolic SAR dapat dijadikan panduan investor dalam membuat keputusa nentry dan exit.

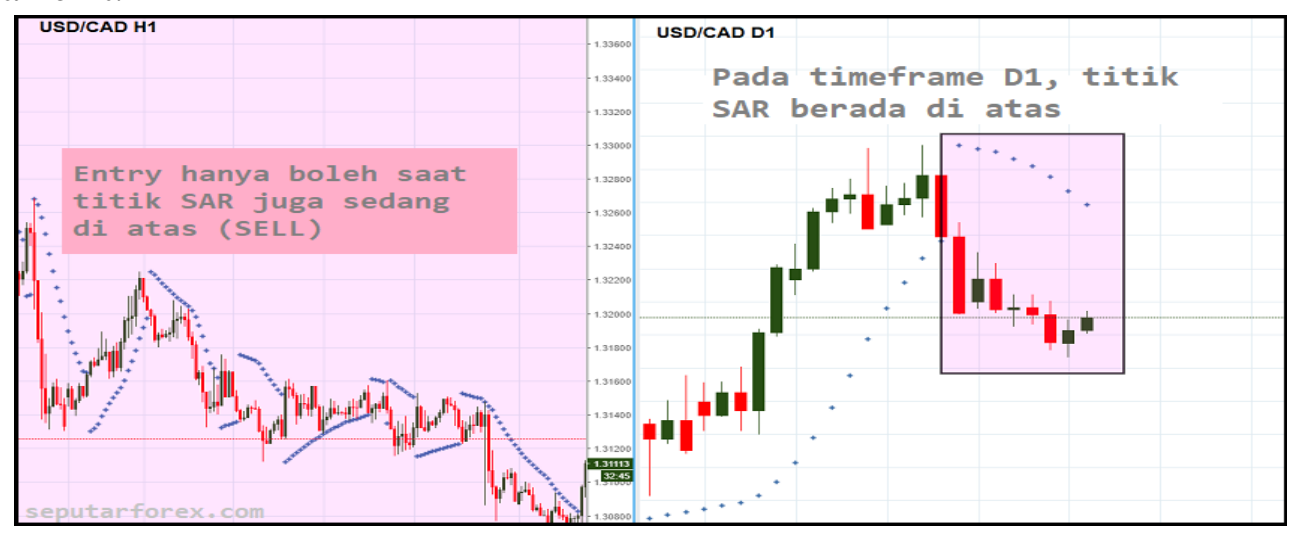

Gambar 22. Contoh Penggunaan Indikaotr Parabolic SAR

Sumber: seputarforex.com, 2018

Sebelum masuk pasar, perhatikan tren dalam timeframe yang lebih besar. Contohnya apabila ingin trading pada pasangan mata uang EUR?USD pada timeframe H1, maka bukalaj terlebih dahulu timeframe D1. Apabila timeframe D1 menunjukkan posisi SAR berada dibawah harga (yang menandakan bahwa EUT/USD sedang uptrend. Maka dalam trading di H1, hanay diperbolehkan membuka posisi Buy saja atau entry saat titik SAR berada dibawah candlestick. dAn ini juga berlaku pada saat posisi Sell. 
Pada saat posisi entry, agar berkurangnya posisi saat pasar sedang dalam konsolidasi, maka sebelum membuka posisi, tunggulah muncul tiga SAR terlebih dahulu.

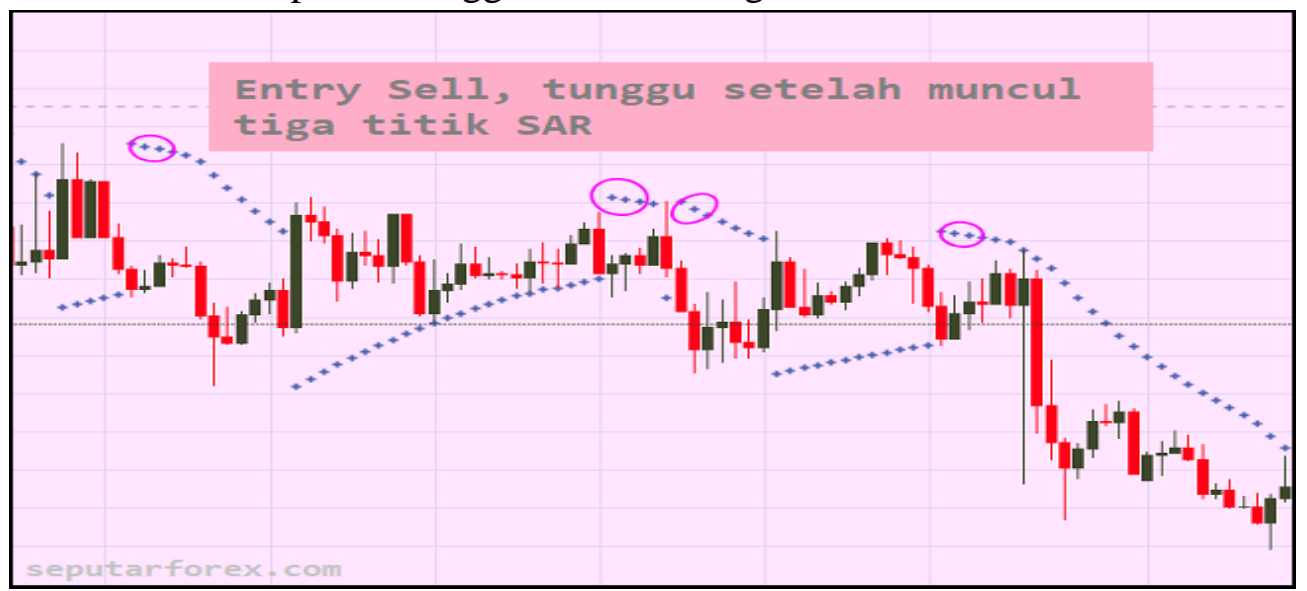

Gambar 23. Contoh Penggunaan Indikaotr Parabolic SAR pada posisi entry

Sumber: seputarforex.com, 2018

Selain entry, indikator Parabolic SAR digunakanjuga untuk tempat exit maupun posisi stop.

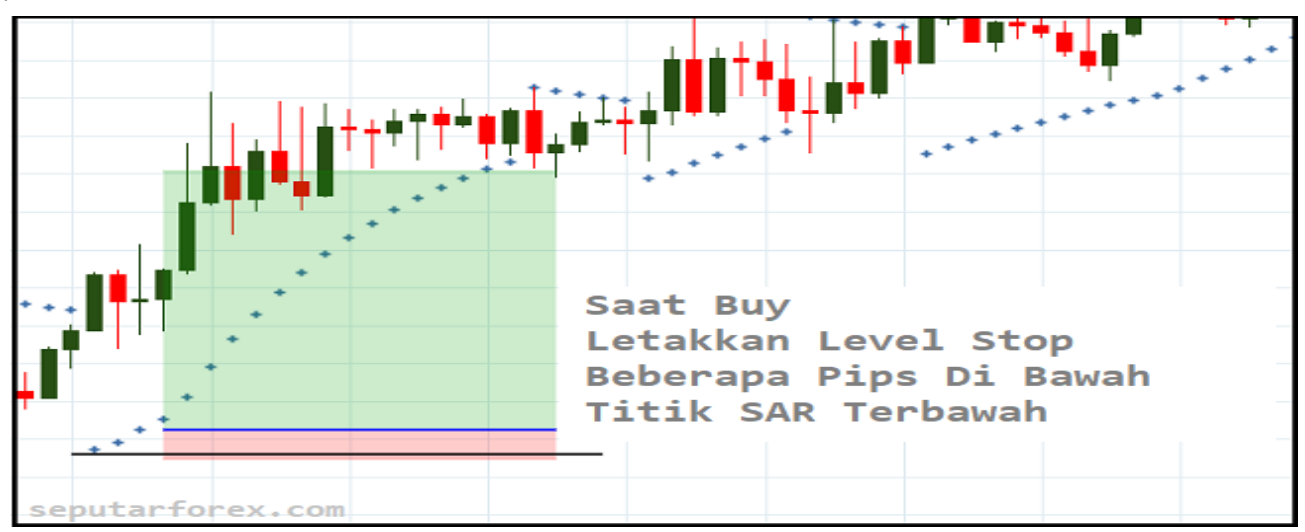

Gambar 24. Contoh Penggunaan Indikaotr Parabolic SAR pada posisi exit atau stop Sumber: seputarforex.com, 2018

Apabila adanya candlestick melewait titik SAR yang berlawanan dengan tren-nya, maka posisi yang sedang terbuka harus segera ditutup.

Penggunaaan indiaktor Parabolic SAR mempunyai kelebihan dalam sifat Trend Following. Dimana harga pad s uatu pasar sedang berlangsung, informais yang tepat tentang trending-nya pasar ini dan ,memberitahukan indiaksi aka nterjadinya pembalikan harga. sEdangkan kelemahanya adalah akan muncul ketikap asarsedang dalam keadaan kosolidasi biasanya Parabolic SAR aka nterus berpindah-pindah dari atas ke bawah dan sebaliknya. Kondisi inilah yang sering menyebabkan False Signal

Beberapa langkah strategis yang digunakan dalam indikator pada analisis teknikal di atas daapt digunakan. Namun, karena perkembangan teknologi yang semakin cepat, kemudahan dalam sistem perdagangan saham untuk membuat poin jual beli berdasarkan parameter analisis teknis harus terus ditingkatkan agar dapat optimal misalnya menggunakan algoritma genetika. Model ini dikembangkan menggunakan platform data besar Apache Spark. Parameter yang 
dioptimalkan kemudian diteruskan ke jairngan saraf MLP yang dalammempredikssi buy-selhold. Dengan mengoptimalkan parameter indikator teknis tidak hanya akan meningkatkan kinerja perdagangan saham tetapi juga mamu menyediakan model yang nantinya dapat digunakan sebagai alternatif untu buy and hold dan model analisis teknis standar lainnya.(Sezer, Ozbayoglu, \& Dogdu, 2017)

Dalam mengembangkan teknik untuk prediksi pasar daftar efek syariah berbasis analisis teknis, maka teknik melibatkan klasifikasi saham berbasis tren, pemilihan indiaktor pasar saham adaptif, dan peramalan sinyal perdagangan pasar saham.(Chen, et al, 2018)

\section{Langkah memilih Saham Daftar Efek Syariah}

Perlu diketahui bahwa langkah -langkah dalam memilih saham dalam daftar efek syariah mempunyai kesamaan dengan memilih saham pada pasar modal secara umumnya. Namun yang menjadi pembeda adalah bahwa dalam daftar efek syariah, seorang investor harus memperhatikan secara khusus apakah perusahaan atau perseroan yang dipilih benar-benar melakukan prinsip-prinsip syariah baik dalam produksinya ataupun operasionalnya. Tidak semua jenis saham terdapat dalam daftar efek syariah tentunya. Karena hal itu menjadi pembeda antara emiten yang pendapatannya tidak dihasilkan dari keuntungan berbasis bunga dan tidak pula didasarkan pada tindakan spekulatif yang tinggi. Dan ini akan memngaruhi keberlangsungan emiten itu sendiri. Memilih Saham Daftar emiten syariah yang bagus untuk diinvestasikan mengacu pada kriteria; 1) memilih saham dengan arah chart dominan $>45^{\circ}$;2) tidak membeli saham daftar efek syariah yang $80 \%$ sideways; 3 ) memilih saham daftar efek syariah yang mempunyai tingkat volatilitas yang tinggi dan secara liquid diperdagangkan setiap hari; 4) memilih emiten datar efek syariah yang mempunyai jumlah saham beredar di pasar cukup banyak. Hal ini dilakukan untuk mengindikasi bahwa floating share kepemilikan dari emiten daftar efek syariah tidak lebih dari 40\%; dan 5) memilih jumlah lot yang cukup banyak sehingga harga saham daftar efek syariah nantinya tidak mudah dipermainkan.(cermati.com, 2019)

\section{KESIMPULAN}

Berdasarkan hasil pembahasan disebutkan bahwa langkah strategis dalam menggunakan analisis teknikal untuk mengambil keputusan investasi saham pada daftar efek syariah memiliki tingkat resiko yang tinggi. Karena analisis teknikal memiliki riskan peluang pembacaan yang dapat membingungkan dan bahkan keliru. Namun fakta bahwa para teknikalis menggunakan beberapa jenis indikator strategis untuk mengambil keputusan investasi adalah tidak diragukan karena sudah hampir 40 taun digunakan dalam berbagai jenis pasar yang berbeda. Meskipun hal ini dapat saja terjadi, dengan menerapkan prinsip - prinsip dan langkah strategis yang tepat maka resiko tersebut dapat diminimalisis. Keahlian dan kehati-hatian dalam mengambil keputusan investasi sangat dibutuhkan, bukan hanya melihat dari sisi keuntungan jangka pendeknya saja. Analisis teknikal tidak cocok bagi individu yang menginginkan investasi jangka waktu yang panjang.

\section{DAFTAR PUSTAKA}


Bollinger, John. Bollinger pada Bollinger Bands . McGraw Hill, 2002. ISBN 978-0-07$\underline{137368-5}$

Cervelló-Royo, R., Guijarro, F., \& Michniuk, K. (2015). Stock market trading rule based on pattern recognition and technical analysis: Forecasting the DJIA index with intraday data. Expert systems with Applications, 42(14), 5963-5975.

Cermati.com. 2017. Tips Memilih Saham Terbaik dengan Analisis Fundamental dan Teknikal. (7 maret 2017). Tercatat di OJK dengan No. S-85/MS.72/2019. Jakarta Barat: PT.Fokus Solusi Proteksi KEP-125/D.05/2014. URL: https://www.cermati.com/artikel/tipsmemilih-saham-terbaik-dengan-analisis-fundamental-dan-teknikal

Cermati.com. 2015. Jenis-jenis Saham yang Wajib Diketaui Investor Pemula. (19 oktober 2015). Tercatat di OJK dengan No. S-85/MS.72/2019. Jakarta Barat: PT.Fokus Solusi Proteksi KEP-125/D.05/2014. URL: https://www.cermati.com/artikel/jenis-jenis-sahamyang-wajib-diketahui-investor-pemula

Chen, Y. J., Chen, Y. M., Tsao, S. T., \& Hsieh, S. F. (2018). A novel technical analysis-based method for stock market forecasting. Soft Computing, 22(4), 1295-1312.

Ding, W., Wang, H., Peng, N., Xiao, Y., \& Liu, Z. (2017, December). Stock Technical Analysis System Based on Real-Time Stream Processing. In 2017 10th International Symposium on Computational Intelligence and Design (ISCID) (Vol. 2, pp. 373-377). IEEE.

Edwards, R. D., Magee, J., \& Bassetti, W. C. (2018). Technical analysis of stock trends. CRC press.

Idx.co.id. 2019. Produk Syariah. 927 november 2019, 16:39). Jakarta Selatan: Bursa Efek Syariah. URL: https://www.idx.co.id/idx-syariah/produk-syariah/

Kiyosaki, Robert T. \& Sharon, L.L. (2002). Rich's Dad Guide To Investing. terj. Bern Hidayat. Jakarta: Gramedia.

Kompasiana.com. 2016. Apa itu Saham Syariah. (27 maret 2016). Jakarta Pusat: Kompas Gramedia.

URL: https://www.kompasiana.com/omega_anjarsari/5747eb13f59273f30540dbdf/apa-itusaham-syariah

Lambert, D. L. (1980). U.S. Patent No. 4,215,247. Washington, DC: U.S. Patent and Trademark Office.

Mardalis (1999). Metode Penelitian Suatu Pendekatan Proposal. Jakarta : Bumi Aksara.

Murphy, J. J. (1999). Technical analysis of the financial markets: A comprehensive guide to trading methods and applications. Penguin.

Seputarforex.com. 2013. Contoh-Contoh dan Pengenalan Analisa Teknikal. (11 april 2013). URL: $\quad$ https://www.seputarforex.com/artikel/contohcontoh-dan-pengenalan-analisateknikal-123403-31

Seputarforex.com. 2014. Trading dengan Stochastic Oscillator. (14 mei 2014). URL: https://www.seputarforex.com/artikel/trading-dengan-stochastic-oscillator-177375-31

Seputarforex.com. 2013. Mengenal Indikator CCI. (23 oktober 2013). URL: https://www.seputarforex.com/artikel/mengenal-indikator-cci-138673-31

Seputarforex.com. 2018. Indikator Moving Average: Fungsi dan Macam-Macamnya. URL: https://www.seputarforex.com/belajar/forex/indikator-moving-average/

Seputarforex.com. 2018. Apa tu Indikator Parabolic SAR. URL: https://www.seputarforex.com/belajar/forex/parabolic-sar/

Seputarforex.com. 2013. Cara Menggunakna Indiaktor Bollinger Bands. URL: https://www.seputarforex.com/artikel/menggunakan-indikator-bollinger-bands-134139$\underline{31}$ 
Sezer, O. B., Ozbayoglu, M., \& Dogdu, E. (2017). A Deep neural-network based stock trading system based on evolutionary optimized technical analysis parameters. Procedia computer science, 114, 473-480.

Wilder, J. W. (1978). New concepts in technical trading systems. Trend Research.

Wong, Wing-Keung, Meher Manzur, and Boon-Kiat Chew. "How rewarding is technical analysis? Evidence from Singapore stock market." Applied Financial Economics 13, no. 7 (2003): 543-551. 